\title{
The Operations/Applications of the Administration of Criminal Justice Law in Edo State
}

\author{
ALABI, AUSTIN ADEBISI, Ph.D \\ Lecturer, Department Of Jurisprudence And International Law, Faculty Of Law, Ambrose Alli University, \\ Ekpoma, Edo State, Nigeria \\ REGINA JEGBEFUMEN OKHIRIA \\ Lecturer, Department Of Jurisprudence And International Law, Faculty Of Law, Ambrose Alli University, \\ Ekpoma, Edo State, Nigeria
}

\begin{abstract}
Various states in Nigeria have passed the Administration of criminal justice bill into law. Lagos state is the first followed by Anambra state. Other states include Ekiti, Ondo, Cross Rivers, Akwa Ibom, Kaduna, Jigawa, and recently Edo State. The Administration of Criminal Justice Law of the states repeals the Criminal Procedure Laws hitherto operational in those states, whereas the Administration of Criminal Justice Act, 2015 which was enacted in 2015 repeals the Criminal Procedure Act, 2010 and the Administration of Justice Commission Act, 2010. The aim and purpose of these enactment is the speedy dispensation of justice whereby both the suspect or defendant and the victim of crime are all treated fairly under the law. The law has also make provisions on how the police should take down statement from the suspect and the ways and methods to treat suspect under their custody. This paper examined the innovation brought by the new law and also identifies the gaps that were present in the old law and how those gaps were adequately filled by the new law. It recommended that a lots still need to be done for the smooth application of the new law.
\end{abstract}

Keywords: criminal justice, operation, application.

DOI: $10.7176 / J L P G / 94-17$

Publication date: February $29^{\text {th }} 2020$

\section{INTRODUCTION}

In Edo State, the Administration of Criminal Justice Law was enacted into law in 2016 and came force in the year 2018. This law repeals the Criminal Procedure Law (Laws of Bendel state of Nigeria 1976) as applicable in Edo State.

The Administration of Criminal Justice Law brought innovations that are quite different from the repealed statute regulating administration of criminal justice, hence at the initial time, stakeholders in the administration of criminal justice were confronted with problems of adapting to the provisions of the Administration of Criminal Justice Law.

The innovations introduced by the Administration of Criminal Justice of Edo State is aimed at making the administration of criminal justice in the state responsive to the demands of the criminal justices sector, and bringing the administration of criminal justice up to date with international best practices. The courts, the lawyers, the police, and the prison who are the stake holders in the administration of criminal justice need constant interactions on the law for easy implementation

Innovations

We shall now consider the innovations introduced by the Administration of Criminal Justice Law of Edo State and challenges of the application of the laws. Some of the innovations in the Edo State Administration of Criminal Justice Law, 2016 include; arrest and detention, recording of confessional statement, remind proceeding, filing of information, plea bargain, award of cost, award of compensation, etc.

Arrest

Section 8 (2) of the Administration of Criminal Justice Law of Edo State prohibits arrest on allegation that borders on civil wrong or breach of contract while Section 7 prohibit arrest in place of the suspect. Sections 8 (2) and (7) of the Administration of Criminal Justice Act ${ }^{1}$ contain identical provisions. This provision however is covered by Chapter IV of the Constitution. ${ }^{2}$

Under the law, any person arrested, whether with or without a warrant shall be taken immediately to the police station or other places authorized to receive arrested persons or suspect, and shall be promptly informed of the allegations against him in the language he understand. While in custody, he shall be given reasonable facilities

\footnotetext{
${ }^{1}$ Administration of Criminal Justice Act, 2015

${ }^{2}$ The Constitution of the Federal Republic of Nigeria, 1999 (as amended).
} 
to obtain legal advice, taking steps to furnish bail and make arrangement for defense or release. ${ }^{1}$ This is in consonance with the provisions of Section 35 of the Constitution. ${ }^{2}$

\section{Record/Recording of Confessional Statement}

Under the law, the police officer making the arrest or the officer in charge is mandated to make two separate records. The first is the recording of the arrest. Under the first head, the officer in charge shall cause to be taking immediately in the form, the following record of the suspect arrested: ${ }^{3}$

a. the alleged offence(s);

b. his date and circumstances of his arrest;

c. his full name, occupation and residential address, and

d. for the purpose of identification;

i. his height

ii. his photograph

iii. his full fingerprint impressions; or

iv. such other means of identification. Under the second head, where a suspect who is arrested with or without a warrant volunteers to make a confessional statement, the police officer shall ensure that the making and taking of the statement shall be in writing and shall be recorded electronically on a retrievable video compact disc or such other audio visual means. ${ }^{4}$

Video recording of the confessional statement of a defendant or suspect makes the job of the prosecution easier during trial within trial. However, most police stations are yet to acquire video recording facilities. The law also requires the presence of a legal practitioner of the suspect choice or any officer of the Legal Aid Council of Nigeria or an official of a Civil Society Organization or a Justice of Peace or anybody of his choice. ${ }^{5}$

\section{Remand Proceedings}

Before now, the practice is that the police arrest a suspect, takes him to a Magistrate court, and slams a charge which the court does not have the jurisdiction on the suspect. The charge will be read to the suspect or defendant but he will not take his plea. Thereafter, the prosecutor mentions the witnesses and exhibits to the court. The court then binds the witnesses over, makes an order remanding the suspect in prison custody and directs the prosecutor to transmit the case file to the Honourable Attorney General for legal opinion and possibly arraignment and thereafter adjourns the matter either to a particular date for report of compliance of the order of transmission of the file to the Honourable Attorney General or adjourn sine die.

This led to so many suspects being dumped and forgotten in the prison custody without any step taken on their case files because, most often or sometimes, the police prosecutors at the Magistrate Court do not transmit the files to the police head quarters for onward transmission to the Honorable Attorney General. At some other times, when the files are transmitted by the police prosecutor at the Magistrate Court to the police headquarters, delay in sorting out the files and transmitting them to the Honourable Attorney General is caused by the inefficient and sometimes, unqualified personnel at the legal unit at the police headquarters.

At other times, when the files are transmitted, the office of the Attorney General may receive them without acting on them. Sometimes, the files may even get lost, then the police and the office of the Attorney General will indulge in trading blames, meanwhile, the suspect remains in custody wasting away. The courts have been consistent over the years in condemning this practice of holding charge unlawful. ${ }^{6}$ Yet, on the face of these pronouncements, holding charge remains a daily occurrence at the magistrate courts. The Administration of Criminal Justice Act and the Administration of Criminal Justice Law has abolished this. ${ }^{7}$

Under the Administration of Criminal Justice Law of Edo State, a suspect or defendant arrested for an offence which a Magistrate Court has no jurisdiction to try shall within reasonable time of arrest be brought before a High Court for remand. ${ }^{8}$ Reasonable time by the provisions of the constitution ${ }^{9}$ means one day where there is a

\footnotetext{
${ }^{1}$ Section 14 of the Administration of Criminal Justice of Edo State, 2016

${ }^{2}$ Supra, note 2.

${ }^{3}$ Section 15 (1), Administration of Criminal Justice Law of Edo State 2016.

${ }^{4}$ Section 15 (4), Administration of Criminal Justice Law of Edo State 2016.

${ }^{5}$ Section 17 (2), Administration of Criminal Justice Law of Edo State, 2016.

${ }^{6}$ See the following cases; Lufadeju .v. Johnson (2007) All WLR (Pt: 37) 1532; Enwerem v. COP (1993) 6 NWLR (Pt 229) 333; Jimoh v. COP (2004) 17 NWLR (Pt: 902) 389.

${ }^{7}$ Section 293 (1) of the Administration of Criminal Justice Act, 2015 and Section 293 (1) of the Administration of Criminal Justice Law of Edo State, 2016.

${ }^{8}$ Supra, Note 9.

${ }^{9}$ Section 35 (5) (a) (b) of the Constitution of the Federal Republic of Nigeria, 1999 (as amended)
} 
court of competent jurisdiction within 40 kilometer radius or two days or such longer period as the court may consider reasonable in any other case.

The defendant shall be brought to the court with form 8 (report and request for remand form) stating;

a. the nature and seriousness of the alleged offence;

b. reasonable grounds to suspect that the suspect has been involved in the commission of the alleged offence;

c. reasonable grounds for believing that the suspect may abscond or commit further offence where he is not committed to prison; and

d. any other circumstances of the case that justifies the request for remand. ${ }^{1}$

The court may, in considering an application for remand brought under Section 193 of this law grant bail to the suspect brought before it, taking into consideration the provisions of Sections 158 to 159 of this law relating to bail. ${ }^{2}$

Where an order of remand of the suspect is made pursuant to section 293 of this law, the order shall be for a period not exceeding fourteen days in the first instance, and the case shall be returnable within the same period. $^{3}$

Where, an application in writing, good cause is shown why there should be an extension of the remand period, the court may make an order for further remand of the suspect for a period not exceeding fourteen days and make the proceedings returnable within the same period. ${ }^{4}$

Where the suspect is still in custody on remand at the expiration of the period provided for under subsection (1) or (2) of this section, the court may on application of the suspect grant bail in accordance with the provisions of sections 158 to 188 of this law. ${ }^{5}$

At the expiration of the remand order made pursuant to subsection (1) or (2) of this section, and where the suspect is still remanded with his trial having not commenced, or charge having not been filed at the relevant court having jurisdiction, the court shall issue a hearing notice on;

a. the Commissioner of Police or the Attorney General of the State; or

b. any relevant authority in whose custody the suspect is or at whose instance the suspect is remanded, and adjourn the matter within a period not exceeding fourteen days of the expiration of the period of remand order made under subsection (1) or (2) of this section, to inquire as to the position of the case and for the Commissioner of Police and the Attorney General of the State to show cause why the suspect remanded should not be unconditionally released. ${ }^{6}$

Where the commissioner of Police and the Attorney General of the state show good cause pursuant to subsection (4) of this section and make a request to that effect, the court;

(a) may extend the remand of the suspect for a final period not exceeding fourteen days for the suspect to be arraigned for trial before an appropriate court; and

(b) shall make the case returnable within the said period of fourteen days from the date the hearing notice was issued pursuant to subsection (4) of this section.?

Where good cause is not shown for the continued remand of the suspect pursuant to subsection (4) of this section, or where the suspect is still on remand custody after the expiration of the extended period under subsection (5), the court shall, with or without an application to that effect, forthwith discharge the suspect and the suspect shall be immediately released from custody. ${ }^{8}$ of this section. ${ }^{9}$

No further application for remand shall be entertained by any court after the proceeding in subsection (6)

\footnotetext{
${ }^{1}$ Section 294 (1) (2) of the Administration of Criminal justice Law of Edo State, 2016

${ }^{2}$ Section 295

${ }^{3}$ Section 296 (1)

${ }^{4}$ Subsection (2)

${ }^{5}$ Subsection (3)

${ }^{6}$ Subsection (4)

${ }^{7}$ Subsection $(5)$

${ }^{8}$ Subsection (6)

${ }^{9}$ Subsection (7)
} 


\section{Filing Information}

Under the Administration of Criminal Justice Law of Edo state, ${ }^{1}$ the Honorable Chief Judge is required to assign an information to a Court within 15 days, and the court is required to issue notice of trial within 10 working days.

Where the defendant named in the information is in custody, the notice of trial and the information shall be delivered to him through the officer in charge of the prison in which he is detained, and the warrant for his production shall be served on the officer of the prison. ${ }^{2}$ personally. ${ }^{3}$

Where the defendant is not in custody, the notice of trial and the information shall be served on him

\section{Plea Bargain}

Under the Administration of Criminal Justice Law of Edo State, the prosecutor is empowered to receive, enter and or negotiate plea bargain. ${ }^{4}$

Plea bargain was alien to criminal justice system or administration in Edo State in particular and Nigeria in general, but was imported into our justice system by the implication of the EFCC Act, ${ }^{5}$ which provides as follows:

Subject to the provisions of Section 174 of the Constitution of the Federal Republic of Nigeria, 1999 (which relates to the power of the Attorney General of the Federation to institute, continue, take over or discontinue criminal proceedings against any person in any court of law), the Commission may compound any offence punishable under this Act by accepting such some of money as it thinks fit not exceeding the maximum amount to which that person would have been liable if he had been convicted of that offences.

The concept of plea bargain itself, originated from the American jurisprudence and became established in the case of Robert M. Brady V. United States. ${ }^{6}$

Subsequently and with this seal of approval by the United State (US) Supreme Court, the Courts treated Plea bargain as contracts between the prosecutors and defendants. If the defendant breaks a plea bargain, the prosecutor is longer not bound by his or her side of the deal. If a prosecutor reneges on plea bargains, defendants may seek relief from the Court. The Court might let them withdraw their guilty pleas, may force the prosecutor to follow the plea bargains or may apply some other remedy.

There can be either sentence bargain or charge bargain. A sentence bargain is where the prosecution agrees to a lesser punishment for the accused if he can plead guilty to the charge. A charge bargain involves the agreements to drop some charge (s) against the accused if he pleads guilty. The advantages of plea bargain include:

i. Accused can avoid the time and cost of defending himself at trial, the risk of harsher punishment and the publicity the trial will involve.

ii. The prosecution saves time and expense of a lengthy trial.

iii. Both sides are spared the uncertainty of going to trial.

iv. The court system is saved the burden of conducting a trial on every crime charged.

Plea bargain was first legislated upon in Nigeria by the Lagos State House of Assembly. This is contained in Section 75 of the Administration of Criminal Justice Law of Lagos State, which provides thus:

Notwithstanding anything in this law, the Attorney General of the State shall have the power to consider and accept a plea bargain from a person charged with any offence where the Attorney General is of the view that the acceptance of such plea bargain is in the public interest, the interest of justice and the need to prevent abuse of legal process.

\section{Cost, Compensation, Damages and Restitution}

The court may, within the proceedings or while passing judgment, order the defendant or convict to pay sum of money.

\footnotetext{
${ }^{1}$ Section $382(1)(2)$

${ }^{2}$ Subsection (3)

${ }^{3}$ Subsection (4)

${ }^{4}$ Section 270

${ }^{5}$ Economic and Financial Crime Act, section 14 (2)

${ }^{6} 397$ US 742 (905 Ct. 1463, 25L. Ed. 2d 747)
} 
a. as compensation to any person injured by the offence, irrespective of any other fine or other punishment that may be imposed or that is imposed on the defendant or convict, where substantial compensation is in the opinion of the court recoverable by civil suit;

b. in compensating a bonafide purchaser for value without notice of the defect of the title in any property in respect of which he was committed and has been compelled to give it up;

c. in defraying expenses incurred on medical treatment of victim injured by the convict in connection with the offence. ${ }^{1}$

Before the enactment of this law, the condition and situation of victim of crime in the state and the country at large was pitiable. One can conveniently and authoritatively say that the Nigerian Criminal Justice and criminal justice system have put in place sufficient and adequate measures to guarantee the interest of and protection for the accused person without similar provision put in place for the protection of victims of crime. Despite these provisions in the State and Federal Statutes, it is also suggested that Federal Government and Edo State in particular should put in place robust welfare packages for their victims of crimes apart from handling the issue of security as of utmost priority.

The Administration of Criminal Justice Law of Edo State established the Criminal Justice Monitoring Committee with the responsibility of ensuring that criminal cases are speedily dealt with. ${ }^{2}$ This is similar to the Administration of Criminal Justice Monitoring Committee created under the Act. ${ }^{3}$

\section{Conclusion}

The Administration of Criminal Justice Law of Edo State is a new innovation which will definitely promote smooth administration of criminal justice in the state. The combine effect of some of the Sections of the law will reduce the time been spent in the determination of many criminal matters. The law will promote justice in the society, both to the suspect or defendant and even to the victim of crime. Another area of concerns which the law has adequately covered is the issue of police arrest of people on purely civil wrong and breach of contract. Our police stations have been turned into debt collection centres whereby policemen are employed by members of the public to assist in enforcing contractual relationship and for recovery of debt. Recording the confessional statement electronically is good but how many police stations in the State have these modern facilities? Some stations do not have electricity, how would such station utilized the equipments if ever they are provided.

The law did not make provisions for the tier of government that will supply the equipments to the various police stations across the State. Is it the Local Government where such stations are located that will provide the equipments or the State or Federal Government.

Most of the provisions in the law may not be realized except some issues raised are urgently and adequately addressed.

Notwithstanding the challenges pointed out in the Administration of Criminal Justice Law of Edo State, 2016. It will undoubtedly facilitate speedy dispensation of Criminal Justice.

\footnotetext{
${ }^{1}$ Section 319 (1) (a-c) of the Administration of Criminal Justice Law of Edo State, 2016

${ }^{2}$ Sections 469 and 470 of the Administration of Criminal Justice Law of Edo State, 2016

${ }^{3}$ Section 469 of the Administration of Criminal Justice Act, 2015
} 